\title{
ANALISIS PERBANDINGAN TIPE PELUMAS BERDASARKAN WUJUD PADA STUDI KASUS PELUMASAN PADA GEARBOX SEPEDA MOTOR
}

\author{
Fadhil Burhannudin Muhammad \\ Jurusan Teknik Mesin, Fakultas Teknik, Universitas Brawijaya ; Jl. Mayjend. Haryono No. 167, \\ Malang,65145, Indonesia \\ Telp. : +62-341-552491; Fax : +62-341-552491 \\ fadhilbeem@gmail.com
}

\begin{abstract}
Lubricants have a very wide application in all aspects of life, including industry and automotive sectors. The main purpose of a lubricant is to keep the moving/sliding surfaces apart, so that friction and consequent destruction of material is minimized. Lubricants can be solid, semisolid, liquid, or gas. The research method in this study composed of data collecting through library method, the theory structures consist of explanation of the advantages and disadvantages of each type of lubricant as well as the working conditions on the given case study. The working conditions of the case study are used as the parameters to the feasibility of lubricants on case study, the parameters are the ability to receive the load, the ability to survive at a speed of 700-3000 rpm, the ability to be circulated, the ability to do the filtering, and the ability to do the cooling. Based on the results obtained from literature study, found that the good ability to receive a load owned by lubricants semi-solid and liquid, the ability to survive at a speed of 700-3000 rpm only owned by liquid lubricant, the ability to be circulated owned by liquid lubricants and gas, the ability to do filtering owned liquid lubricant and gas, and the ability to perform cooling owned by liquid lubricant and gas. Based on the results of the final analysis, the best lubricant that suitable for the case study is liquid lubricant.
\end{abstract}

Keywords: Pelumas, Wujud Pelumas, Gearbox

\section{PENDAHULUAN}

Pelumas memiliki aplikasi yang sangat luas di segala lini kehidupan, tak terkecuali dalam bidang industry dan otomotif. Hal ini berkenaan langsung dengan perawatan dan efisiensi dari mesin industry. Pelumasan memiliki peran berupa pengurangan gesekan dan sebagai penghilang panas pada dua bidang yang berkontak. Dalam proses permesinan, proses pelumasan dapat berfungsi sebagai pendingin untuk mencegah cacat panas yang menyebabkan kecacatan pada logam.

Pelumas dapat berupa wujud gas, cair, semi solid, atau gas yang dapat menerima gaya secara bebas dari peralatan peralatan mekanik dan mencegah kerusakan oleh abrasi dan pengurangan ukuran dari logam atau komponen lain melalui ekspansi tidak sejenis yang dikarenakan panas. Namun tiap tiap tipe pelumas tersebut memiliki kemampuan yang berbeda pada kondisi tertentu sehingga penerapannya juga berbeda. Kondisi tersebut dapat berupa pembebanan yang besar maupun kondisi pada objek yang mengalami gesekan pada kecepatan yang sangat tinggi. Perbedaan kondisi tersebut menjadi salah satu syarat utama dalam pemilihan tipe pelumas karena tiap tipe pelumas tersebut memiliki karakteristik yang mendasari kemampuan yang dimiliki. Oleh karena itu, diperlukan studi komparasi mengenai tipt tipe pelumas berdasarkan wujudnya dimana studi kasus yang dijadikan parameter adalah pada gearbox sepeda motor.

\section{METODOLOGI PENELITIAN}

A. Metode Pengambilan Data

Dalam penelitian ini menggunakan

Metode Penelitian Kepustakaan (Library Research). Metode ini digunakan dalam mendapatkan data dengan cara observasi dengan literatur yang digunakan. Kemudian juga dengan membaca sumber-sumber data informasi lainnya yang berhubungan dengan pembahasan. Sehingga dengan penelitian kepustakaan ini diperoleh secara teori mengenai permasalahan yang dibahas. Selain itu, jenis penelitian yang dilakukan adalah studi komparasi. dimana masing masing subjek 
penelitian akan dihadapkan pada studi kasus sehingga dapat diketahui manakah subjek penelitian yang sesuai dengan studi kasus tersebut.

\section{B. Kerangka Pemikiran}

Berdasarkan kekuatan geser dari pelumas atau keadaan molekulnya, pelumas terbagi menjadi 4 kategori, antara lain pelumas fase padat, pelumas fase semi padat, pelumas fase gas, dan pelumas fase cair.

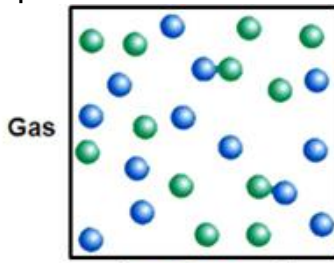

Liquid

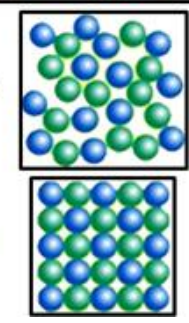

Gambar 1. Fase -Fase pada Berbagai Jenis Pelumas [1].

1. Pelumas fase padat

Pelumas fase solid didasari oleh material padat yang ditempatkan diantara dua permukaan bearing dan akan bergesekan dengan lebih mudah dibawah beban yang diberikan dibandingkan ketika diberikan beban dibandingkan dengan material bearing itu sendiri [1]. Koefisien gesek pada pelumasan kering tergantung dari gaya gesek dan beban bearing. Dua properti primer yang dibutuhkan pada pelumasan kering adalah material harus mampu mengimbangi beban yang diberikan tanpa terjadi distorsi, deformasi, maupun losses dalam kekuatan dan koefisien gesek dan laju keausan haruslah rendah.

- Karakteristik pelumas padat

Kelebihan:

1. Kemampuan untuk bekerja dibawah beban berat.

2. Kemampuan untuk stabil pada temperature tinggi.

3. Dapat dioperasikan pada kondisi kotor jika dibandingkan dengan pelumas cair maupun semi padat yang tidak dapat mentolerir masuknya kontaminan (debu) [2].

Kekurangan:

1. Koefisien gesek dan aus yang lebih besar dibandingkan pelumas fluida.

2. Kestabilan yang rendah pada lapisan pelumasan (tidak rata).

3. Tidak terdapatnya system pengaliran pelumas pada permukaan yang bergesekan. Tidak seperti pelumas dengan fluida (cair atau gas) yang memiliki system pengisian, penyaringan, dan pendinginan secara kontinyu [3].

- Klasifikasi pelumas padat:

1. Polimer

Pelumas ini cocok digunakan untuk menerima beban ringan. Sebagai subclass pelumas padat, PTFE, Nilon dan polimer sintetik biasa digunakan secara umum sebagai pelumas padat.

a. Poly Tetra Fluoro Ethylene (PTFE)

Poly tetra fluoro ethylene merupakan polimer yang diproduksi dari etilen dimana seluruh atom hidrogennya digantikan oleh atom atom fluorine. Teflon merupakan nama pasar PTFE yang diberikan $D u$ Pont. Keunggulannya adalah berat yang ringan dalam aplikasi. Sifat adhesi PTFE yang buruk dibandingkan material lain, dimana $\mu(<0.1)$.

Keunggulan PTFE:

- Kestabilan reaksi terhadap bahan kimia yang tinggi, sifat inert kimia yang tinggi, dikarenakan ikatan karbon dan fluorin yang kuat.

- Energi permukaan yang rendah, gesekan yang rendah (0.1), $\mathrm{p}$ yang tinggi, $v$ yang rendah.

- Tidak beracun, sehingga dapat digunakan dalam keperluan industri ataupun farmasi.

Kelemahan PTFE:

- Terlalu lembut (tidak keras), laju keausan yang tinggi.

- Ketahanan mulur yang rendah, kapasitas beban yang rendah.

- Konduktivitas termal yang buruk, ekspansi panas yang tinggi, batas temperatur $\left(250^{\circ} \mathrm{C}\right)$.

- Ketika terjadi vakum, makan akan mengakibatkan penurunan unjuk kerja. 
b. Nilon

Serupa dengan PTFE, tetapi sedikit lebih keras (laju spesifik keausan : 10,6 $10,5 \mathrm{~mm}^{3} /$ menit).

c. Synthetic polymers

Komposit polimer memiliki laju keausan yang tinggi bergantung pada kekasaran permukaan dari permukaan logam. Pada fase pengoperasian tertentu, keausan sangat signifikan tetapi dapat dikurangi dengan menyediakan permukaan yang halus. Ketika waktu proses telah selesai, laju keausan dapat dikurangi dengan pemindahan lapisan polimer atau dengan proses pemolesan diantara permukaan yang bergesekan. Konduktivitas termal yang rendah bersifat menghalangi hilangnya panas dimana dapat menyebabkan kegagalan awal akibat pelelehan.

2. Pelumas Padat Logam

Pelumas ini mengandung padatan pipih yang bergantung pada pemindahan lapisan untuk mendapatkan gesekan yang rendah tetapi pemindahan kontinyu lapisan mungkin dapat mengurangi umur komponen, karena itu sering disebut "no lamellar solids" yang ditambahkan ke padatan pipih yang berkarakteristik rendah gesekan. Untuk mendapatkan tujuan tujuan tersebut, dibuatlah lubang dengan memakai komponen mesin dan lubang lubang tersebut diisi dengan pelumas padat. Terdapat bermacam macam teknik yang digunakan dalam produksi komposit semi padat. Hal tersebut termasuk metalurgi serbuk, infiltrasi, plasma spraying, dan metode electrochemical code position.

Molybdenum Disulfide merupakan jenis yang paling banyak digunakan dalam pelumas fase semi padat.

Keunggulan $\mathrm{MoS}_{2}$ :

- Mampu menahan beban berat (>700 Mpa)

- Rendah gesekan

- Memiliki temperatur pelumas yang tinggi terutama pada ruang

Kelemahan $\mathrm{MoS}_{2}$ :

- Kerugian akibat kelembaban yang dapat mengurangi performa pelumas

- Ketebalan lapisan $15 \mu \mathrm{m}$

\section{Karbon dan Grafit}

Kestabilan pada kondisi panas yang tinggi dan oksidasi menyebabkan karbon dan grafit mampu untuk kondisi panas yang tinggi dan kondisi benda yang bergesekan dengan kecepatan tinggi..

Kelebihan grafit:

- Mampu menerima beban sedang $(<275$ $\mathrm{MPa}$ ).

- Rendah gesekan.

- Kestabilan pada temperature yang tinggi.

Kekurangan grafit :

- Korosi.

- Kehilangan performa pada kondisi vakum.

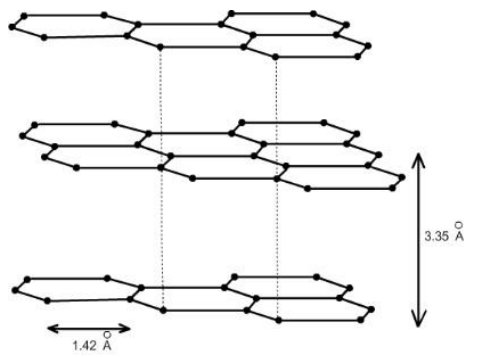

Gambar 2. Struktur grafit [1]

4. Pelapisan ceramic dan Cermet (Ceramic and Metal) coatings

Ceramic dan cermet dapat digunakan dalam aplikasi dimana laju keausan lebih kritis daripada gesekan yang rendah. Komposit ini dapat digunakan pada rentang temperature $0-1000^{\circ} \mathrm{C}$. Pelapisan ceramic dan cermet dapat setebal hingga $0.5 \mathrm{~mm}$ dan memberikan ketahanan keausan pada logam. Pelapisan pada ceramic dan cermet dapat diaplikasikan pada:

- Plasma spraying.

- Pelapis trigger dari pistol (peningkatan adhesi logam substrat dan porositas rendah)

- Electrolytic deposition dari elektrolit yang terdapat pada partikel partikel keramik (Tribomet coating). Kemampuan untuk melapisi permukaan yang sulit dijangkau.

2. Pelumas fase semi-padat (Grease)

Pelumasan dengan grease mengandung minyak pelumas, biasanya dengan viskositas 
yang rendah. grease mengandung (75 hingga $95 \%$ ), zat adiktif (0 hingga $5 \%$ ) and serat penebal (5 hingga $20 \%$ ).

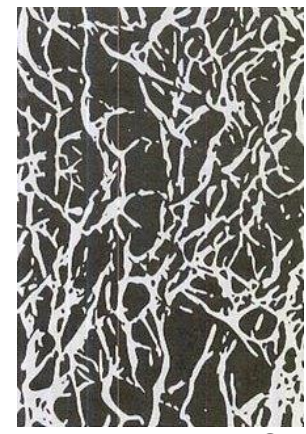

Gambar 3. Pelumas Fase Semi Solid [1]

1. Kelebihan grease :

- Digunakan pada subjek dengan intensitas penggunaan yang rendah.

- Cocok untuk penggunaan poros vertical.

- Mencegah molekul asing masuk.

- Tahan air dan mengurangi masalah penguapan minyak.

- Mempunyai pelumasan bantalan mekanik yang lebih baik pada kondisi ekstrim seperti pembebanan kejut, pengoperasian terbalik (reversing operations), cocok digunakan pada kecepatan rendah dan beban yang tinggi.

- Mengurangi noise dan getaran.

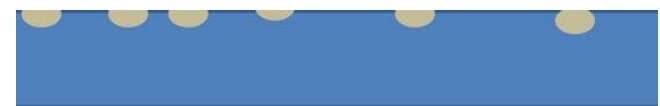

Gambar 4. Penyimpangan pada pengisian Grease [1]

2. Kekurangan Grease :

- Karena sifat alami fase semi-dolid dari grease, maka grease tidak dapat melakukan pendinginan, dan memiliki kemampuan penghilang panas yang buruk.

- Sekali debu atau molekul pengotor lainnya mamasuki grease, makan grease akan sulit dihilangkan sehingga dapat mengurangi performa.

- Tidak ada proses penyaringan. Dimana hal ini tidak dapat terjadi pemisahan pada kontaminan,

3. Karakteristik Grease Characteristics

- Konsistensi: derajat kekasaran grease
- Permukaan grease (perlakuan pada suhu $25^{\circ} \mathrm{C}$ ) dibuat lembut agar seragam.

- Mekanisme pelepasan cone diaktivasi dan cone dibiar tertutupi selama 5 detik.

- Grease merupakan memiliki wujud fulida pseudo - plastic.

3. Pelumas Cair

1. Klasifikasi pelumas cair:

a. Minyak sayur:

- Kurang stabil (oksidasi yang berlebihan) daripada minyak mineral pada temperature tinggi

- Memiliki lebih banyak batas-batas pelumas daripada minyak mineral.

b. Gemuk binatang / Fixed oils : fixed oils sangat lambat mengalami pengeringan dan pernah digunakan dalam pelumasan. Fixed oils biasanya dijadikan sebagai tambahan pada minyak mineral untuk meningkatkan formasi lapisan pada pelumas dimana pelumas ini memiliki property tahan pada tekanan ekstrim. Contoh pelumas ini adalah tallow, castor oil and fish oil. Hanya satu permasalahan pada pelumas ini adalah masalah ketersediaan.

c. Minyak mineral

Diekstrak dari crude oil. Minyak mineral mengandung hidrocarbon (disusun dari $83-87 \%$ karbon and 11$14 \%$ hydrogen) dengan perkiraan 30 atom karbon disetiap molekul (disusun dari rantai lurus dan melingkar yang mengikat satu sama lain). Juga mengandung sulfur, oksigen, nitrogen.

Minyak mineral diklasifikasikan lagi menjadi paraffin, naphthene and aromatic. Paraffin lebih sering digunakan daripada atau or aromatics.

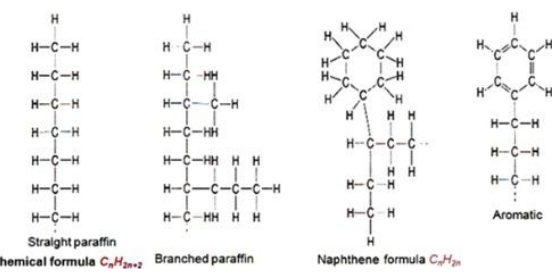

Gambar 5. Bentuk-bentuk dari minyak mineral [1] 
i. Minyak Paraffinic

Minyak Paraffinic memiliki ketahanan alami terhadap oksidasi terhadap asam, tetapi jika mengalami oksidasi akibat terbakar, maka akan meninggalkan zat sisa berupa zat karbon..

- Kestabilan termal yang baik.

- Laju penguapan yang rendah.

- Indeks viskositas yang tinggi (VI=90-115).

- Flash point yang tinggi.

- Pour point yang lebih tinggi dari naphthenic ataupun aromatic.

ii. Minyak Naphthenic

- Indeks viskositas yang lebih rendah (15-75).

- Ketahanan oksidasi yang kurang.

- Flash points daripada paraffinic.

- pour point daripada paraffinic meskipun bagus untuk aplikasi pada temperature rendah.

- Ketika terbakar,akan terbentuk zat sisa, meskipun abrasive wear -nya rendah.

iii. Minyak Multigrade

Sebagian besar minyak rak saat ini berupa minyak multigrade, seperti 10W30 ataupun 20W50. Minyak ini dibuat dari penambahan polymers dalam minyak mineral untuk menaikkan indeks viskositas.

iv. Minyak Sintetis

Minyak sintesis dibuat secara khusus untuk menangani kondisi yang ekstrem, seperti pada mesin jet.

- Viskositas tidak berpengaruh terhadap temperatur seperti halnya dengan mineral oil.

- Laju oksidasi lambat.

- Kestabilan oksidasi yang baik

- Memiliki properti anti aus yang baik

- Pembentukan residu yang rendah

- Sifat pelumasan yang baik

- Biaya(mahal, tetapi sangat aplikatif dimana mineral oil tidak memadai).

\section{Pelumas Gas}

Pelumasan gas (i.e, Air, Nitrogen, and Helium) digunakan pada lapisan dengan ketebalan (jarak pemisah) ultra tipis di antara komponen-komponen dalam tribologi
Keuntungan :

- Rentang temperatur $\left(-200^{\circ} \mathrm{C}\right)$ hingga $\left(2000^{\circ} \mathrm{C}\right)$. Tidak ada penguapan, kavitasi, pembekuan atau pemadatan, dan dekomposisi.

- Viskositas yang sangat rendah (1000 kali lebih cair daripada mineral oil), meskipun begitu, pelumas gas memiliki gesekan yang rendah sehingga cocok pada putaran tinggi.

- Bersih.

- Tidak memerlukan segel dalam pelumasan (seperti pelumas semi padat dan pelumas cair).

Kerugian :

- Kapasitas beban yang sangat rendah c [4],

- peredaman yang rendah, serta ketebalan lapisan yang sangat tipis.

- Permukaan yang halus dan sangat presisi (untuk memaksimalkan beban dan meminimalkan laju aliran) memutuhkan desainer yang spesial atau ahli manufaktur (khusus toleransi sempit)

- Sulit mentolerir error terkait estimasi pembebanan dan penurunan spesifikasi ketika proses manufafktur dan proses instalasi.

- Permukaan hasil finishing harus ekstra halus [4]

- Suaian pada pelumasan gas harus sangat teliti

- Dimensi dan clearance harus ekstra akurat

- Kecepatan putar harus tinggi

- Beban harus rendah

- Proses desain harus dilakukan secara hati hati untuk menghindari getaran akibat sifat mampu kompresi dari fluida

- Dibutuhkan kekuatan lebih untuk mengkompresi fluida

- Diperlukan perhitungan yang lebih empiris terkait hubungan aliran pada fluida karena sangat sulit untuk diselesaikan

- Diperlukan proses manufaktur yang sangat presisi

C. Kondisi Kerja Pelumas pada Studi Kasus

Dalam menentukan tipe pelumas yang diigunakan, maka harus diperhatikan beberapa hal, diantaranya beban (tipe dan arah beban), tipe bearing (jika dibutuhkan), temperature, metode pelumasan, dan 
kondisi lingkungan (apakah kotor, berair, dan sebagainya) [5].

Secara umum, kondisi kerja putaran mesin sebelum memasuki gearbox pada sepeda motor yang digunakan harian (tidak sampai putaran tinggi / diatas 6000 rpm) bekerja pada putaran kurang lebih $1400-6000 \mathrm{rpm}$. Setelah putaran mesin diteruskan ke gearbox, maka akan mengalami peruksian putaran hingga menjadi kurang lebih $700-3000$ rpm. Selain itu, temperature kerja mesin dapat mencapai suhu diatas $90{ }^{\circ} \mathrm{C}$. pada penelitian ini, contoh yang digunakan adalah mesin Honda Revo 100cc sebagai subjek perbandingan tipe pelumas. Berikut gambar bagian bagian yang mengalami pelumasan:

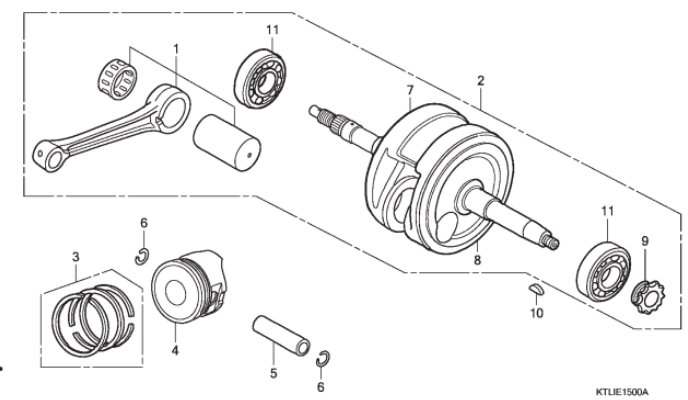

Gambar 6. Crankshaft / Piston [6]

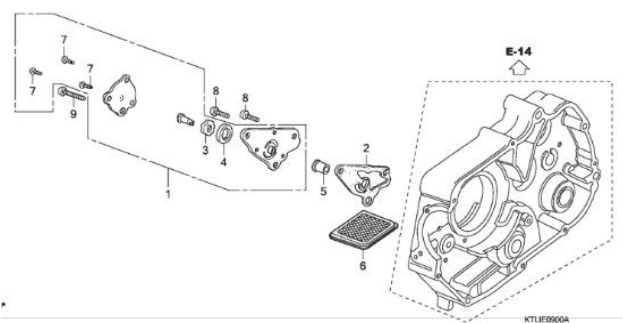

Gambar 7. Pompa Oli [6]

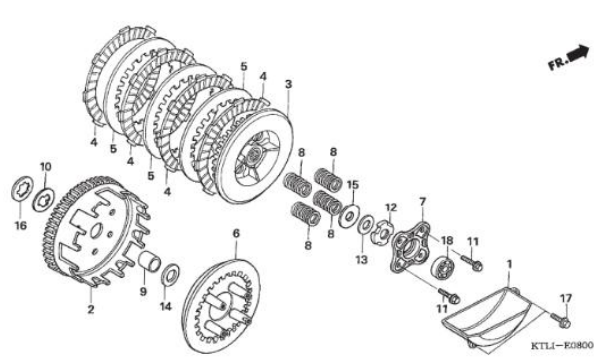

Gambar 8. Kopling [6]

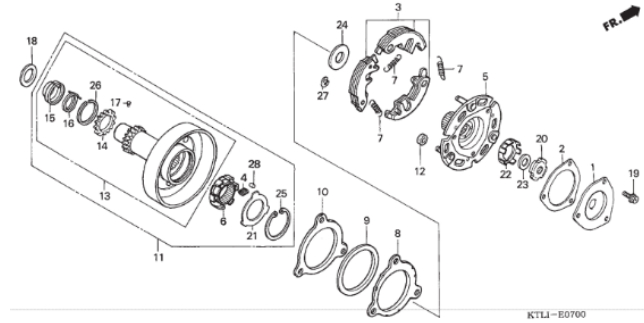

Gambar 9. Kopling Sentrifugal [6]

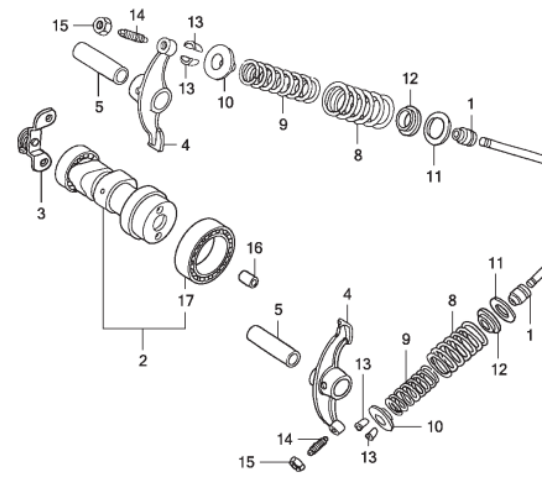

Gambar 10. Komponen pada Kepala Silinder [6]

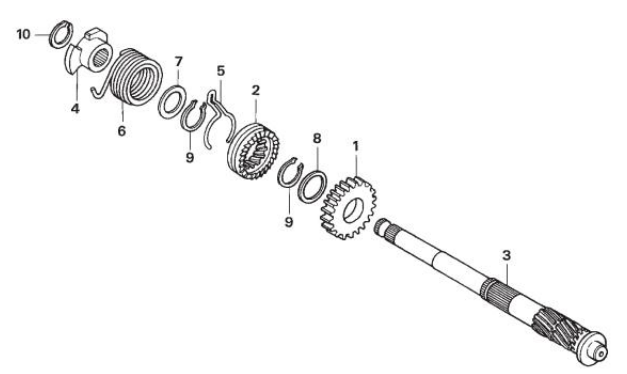

Gambar 11. Kick Starter Spindle [6]

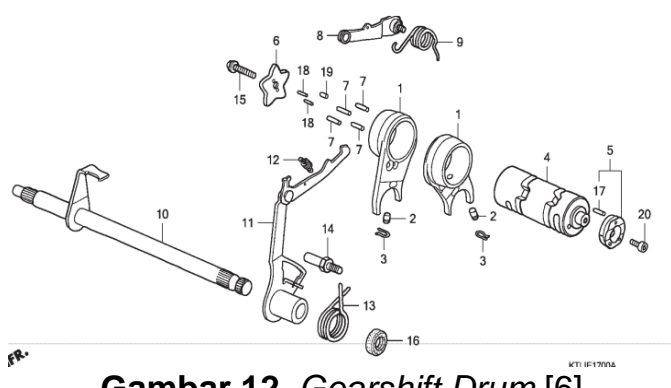

Gambar 12. Gearshift Drum [6] 


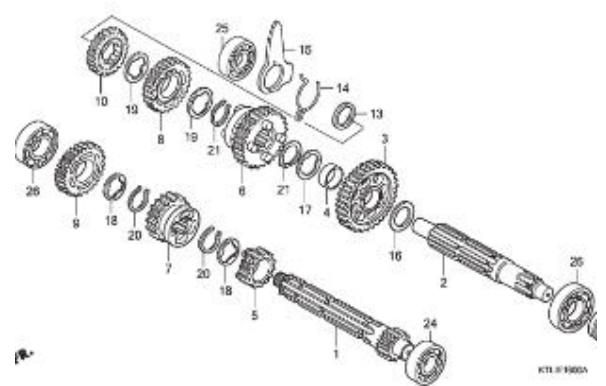

Gambar 13. Transmission [6]

\section{Flowchart Penelitian}

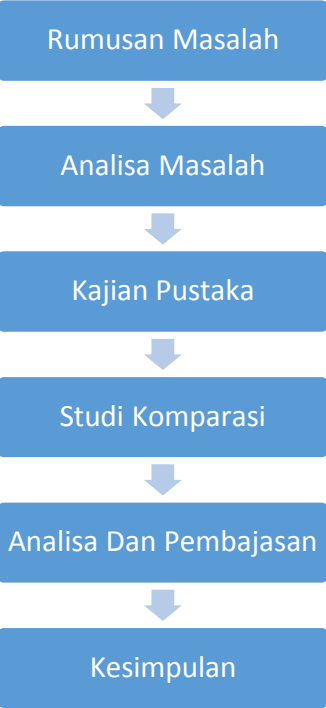

HASIL DAN PEMBAHASAN

Tabel 1. Perbandingan Kelebihan dan Kekurangan dari Tiap Tipe Pelumas

\begin{tabular}{|c|c|c|c|c|}
\hline & \multicolumn{4}{|c|}{ Tipe Pelumas } \\
\hline & Padat & Semi-padat & Cair & Gas \\
\hline \multirow{6}{*}{ Kelebihan } & $\begin{array}{c}\text { Dapat menggantikan pelumas semi padat dan } \\
\text { pelumas cair jika kondisi pelumasan pada kedua } \\
\text { tipe pelumas tidak aman bagi bidang yang } \\
\text { bergesekan, jika kondisi bidang pelumasan pada } \\
\text { kedua tipe pelumas tidak boleh terkena } \\
\text { kontaminan (seperti debu), Kondisi pengoperasian } \\
\text { pada beban yang tinggi ataupun temperature yang } \\
\text { tinggi. }\end{array}$ & $\begin{array}{c}\text { Mempunyai pelumasan bantalan } \\
\text { mekanik yang lebih baik pada } \\
\text { kondisi ekstrim seperti } \\
\text { pembebanan kejut, pengoperasian } \\
\text { terbalik (reversing operations), } \\
\text { cocok digunakan pada kecepatan } \\
\text { rendah dan beban yang tinggi. }\end{array}$ & Ketersediaan yang selalu siap (tidak sulit dicari) & $\begin{array}{l}\text { Rentang temperatur }\left(-200^{\circ} \mathrm{C}\right) \text { hingga }\left(2000^{\circ} \mathrm{C}\right) . \\
\text { Tidak ada penguapan, kavitasi, pembekuan } \\
\text { atau pemadatan, dan dekomposisi. }\end{array}$ \\
\hline & $\begin{array}{l}\text { Lebih efektif daripada pelumas cair dalam hal } \\
\text { menerima beban berat (tekanan tinggi) }\end{array}$ & $\begin{array}{l}\text { Cocok untuk penggunaan poros } \\
\text { vertical. }\end{array}$ & Rendah biaya & $\begin{array}{l}\text { Viskositas yang sangat rendah (1000 kali lebih } \\
\text { cair daripada mineral oil), meskipun begitu, } \\
\text { pelumas gas memiliki gesekan yang rendah } \\
\text { sehingga cocok pada putaran tinggi. }\end{array}$ \\
\hline & $\begin{array}{c}\begin{array}{c}\text { Memiliki Ketahanan tinggi dari penurunan kualitas } \\
\text { produk ketika dilakukan penyimpanan }\end{array} \\
\end{array}$ & Mencegah molekul asing masuk. & $\begin{array}{c}\text { Dapat dilakukan proses sirkulasi, penyaringan, } \\
\text { dan penghilangan panas }\end{array}$ & $\begin{array}{c}\begin{array}{c}\text { Bersih, dan level getaran dan kebisingan yang } \\
\text { rendah }\end{array} \\
\end{array}$ \\
\hline & $\begin{array}{c}\text { Kestabilan yang tinggi pada kondisi ektrim, seperti } \\
\text { temperatur ekstrim, radiasi, dan lingkungan yang } \\
\text { reaktif }\end{array}$ & $\begin{array}{c}\text { Tahan air dan mengurangi masalah } \\
\text { penguapan minyak. }\end{array}$ & Viskositas yang rendah & $\begin{array}{l}\text { Tidak memerlukan segel dalam pelumasan } \\
\text { (seperti pelumas semi padat dan pelumas cair). }\end{array}$ \\
\hline & $\begin{array}{l}\text { Dapat menggunakan peralatan yang lebih ringan } \\
\text { dan simpel }\end{array}$ & $\begin{array}{l}\text { Digunakan pada subjek dengan } \\
\text { intensitas penggunaan yang } \\
\text { rendah. }\end{array}$ & $\begin{array}{c}\text { Mampu menghilangkan panas karena dapat } \\
\text { bersirkulasi }\end{array}$ & \\
\hline & Memiliki tingkat kebersihan yang sangat baik & Mengurangi noise dan getaran. & & \\
\hline \multirow{4}{*}{ Kekurangan } & $\begin{array}{l}\text { Memiliki properti pengembalian kondisi semula } \\
\text { yang buruk. Permukaan lapisan cenderung memiliki } \\
\text { umur yang singkat. }\end{array}$ & $\begin{array}{c}\text { Tidak efektif dalam } \\
\text { menghilangkan panas dari bearing, } \\
\text { sehingga hanya dapat bekerja pada } \\
\text { temperatur rendah }\end{array}$ & Dapat terjadi kebocoran, karena memakai seal & $\begin{array}{c}\text { Sulit mentolerir error terkait estimasi } \\
\text { pembebanan dan penurunan spesifikasi ketika } \\
\text { proses manufafktur dan proses instalasi. }\end{array}$ \\
\hline & $\begin{array}{l}\text { Penghilangan panas yang buruk. Kondisi ini } \\
\text { dikarenakan material berupa polimer dimana } \\
\text { memiliki konduktivitas termal yang buruk. }\end{array}$ & $\begin{array}{c}\text { Sekali debu atau molekul pengotor } \\
\text { lainnya mamasuki grease, makan } \\
\text { grease akan sulit dihilangkan } \\
\text { sehingga dapat mengurangi } \\
\text { performa. }\end{array}$ & $\begin{array}{c}\text { Jika pelumas cair terbakar, maka akan } \\
\text { meninggalkan residu berupa zat oksida (kerak } \\
\text { hitam) }\end{array}$ & $\begin{array}{l}\text { Permukaan yang halus dan sangat presisi } \\
\text { (untuk memaksimalkan beban dan } \\
\text { meminimalkan laju aliran) memutuhkan } \\
\text { desainer yang spesial atau ahli manufaktur } \\
\text { (khusus toleransi sempit) }\end{array}$ \\
\hline & $\begin{array}{l}\text { Memiliki koefisien gesek dan aus yang lebih besar } \\
\text { dari pelumas cair pada bearing }\end{array}$ & $\begin{array}{l}\text { Tidak ada proses penyaringan. } \\
\text { Dimana hal ini tidak dapat terjadi } \\
\text { pemisahan pada kontaminan }\end{array}$ & & $\begin{array}{l}\text { Peredaman yang rendah, serta ketebalan } \\
\text { lapisan yang sangat tipis. }\end{array}$ \\
\hline & & & & Kapasitas beban yang sangat rendah \\
\hline
\end{tabular}


Analisa Perbandingan Kelebihan dan Kekurangan Secara Umum dari Tipe-Tipe Pelumas

Pada studi ini, analisa dijabarkan dalam bentuk tabel dimana masing masing tabel menyajikan keterangan tiap tipe pelumas baik kelebihan, kekurangan dan kemampuan pelumas pada kondisi tertentu. Pada tabel 1 dapat dilihat kelebihan dan kekurangan dar masing masing tipe pelumas berdasarkan literatur. Dengan tabel 1. Kita dapat mengetahui karakteristik dari tiap tipe pelumas secara umum sehingga dapat dilakukan analisa terhadap studi kasus.

Tabel 2. Perbandingan Kemampuan Tiap Tipe Pelumas pada Kondisi Kerja Mesin Sepeda Motor Revo $100 \mathrm{cc}$

\begin{tabular}{|c|c|c|c|c|c|}
\hline & \multicolumn{5}{|c|}{ Pelumasan pada Studi Kasus Mesin Sepeda Motor } \\
\hline & $\begin{array}{c}\text { Kemampuan } \\
\text { Menahan } \\
\text { Beban }\end{array}$ & $\begin{array}{l}\text { Kemampuan } \\
\text { pada Putaran } \\
700 \text { - } 3000 \text { rpm }\end{array}$ & $\begin{array}{c}\text { Kemampuan } \\
\text { Sirkulasi } \\
\text { pelumas }\end{array}$ & $\begin{array}{c}\text { Kemampuan } \\
\text { Pelumas } \\
\text { untuk } \\
\text { Disaring }\end{array}$ & $\begin{array}{c}\text { Kemampuan } \\
\text { Mendinginkan }\end{array}$ \\
\hline $\begin{array}{c}\text { Pelumas } \\
\text { Padat } \\
\text { (serbuk } \\
\text { grafit) }\end{array}$ & $\checkmark V V^{*}$ & $\mathrm{~V}^{*}$ & - & - & - \\
\hline $\begin{array}{l}\text { Pelumas } \\
\text { Semi } \\
\text { Padat } \\
\text { (grease) }\end{array}$ & $\mathrm{V} V \mathrm{~V}$ & v & - & - & $\sqrt{ }$ \\
\hline $\begin{array}{l}\text { Pelumas } \\
\text { Cair }\end{array}$ & $\mathrm{V} V$ & $\mathrm{~V} V \mathrm{~V}$ & $\mathrm{~V} V \mathrm{~V}$ & $\mathrm{~V} V \mathrm{~V}$ & $\mathrm{~V} V \mathrm{~V}$ \\
\hline $\begin{array}{l}\text { Pelumas } \\
\text { Gas }\end{array}$ & - & - & $\mathrm{V} V \mathrm{~V}$ & $\mathrm{~V} V$ & $\mathrm{~V} V \mathrm{~V}$ \\
\hline
\end{tabular}

Keterangan :

$\mathrm{V} V \mathrm{~V}$ : Sangat baik

$\mathrm{VV}$ : Cukup baik

$\checkmark \quad$ : Kurang layak

- : :Tidak layak

* : Terdapat pengecualian

\section{Analisa Perbandingan Tipe Pelumas Terhadap Studi Kasus}

Studi kasus yang diambil pada studi komparasi ini adalah pelumasan pada mesin sepeda motor Honda Revo 100 cc. Dengan bagian yang mengalami pelumasan adalah Crankshaft / Piston, kopling, kopling sentrifugal, Komponen pada Kepala Silinder, pompa oli Kick Starter Spindle, Gearshift Drum, dan Transmission. Adapun tabel perbandingan kemampuan tiap tipe pelumas disajikan pada tabel 2.
Tabel 2. diatas menunjukkan kemampuan dan kelayakan sistem pelumasan dari tiap tipe pelumas pada studi kasus mesin sepeda motor Honda Revo 100 cc. Adapun Kemampuan yang dibandingkan adalah Kemampuan menahan beban, Kemampuan pada putaran 700-3000 rpm, kemampuan mensuplai, menyaring, dan mendinginkan pelumas.

- Pelumas Padat

Berdasarkan tabel diatas, pelumas padat mem iliki kemampuan menahan beban yang sangat baik dan Kemampuan pada putaran 700-3000 rpm yang cukup baik namun kedua sifat tersebut hanya sementara. Berdasarkan kerangka berfikir sebelumnya, $\mathrm{Hal}$ ini dikarenakan pelumas padat yang bersifat mudah hilang pada permukaan yang dilapisinya. Pada pelumas padat tidak terdapatnya proses 
sirkulasi terlebih proses penyaringan (karena penyaringan terletak pada sistem siskulasi). Tidak adanya proses sirkulasi, menyebabkan tidak terjadinya proses pendinginan oleh pelumas, akibatnya komponen pada mesin akan cepat aus.

- Pelumas Semi Padat

Pada pelumas semi padat, kemampuan menahan beban sangat baik, kemampuan pada putaran 700-3000 rpm yang kurang baik serta tidak adanya proses penyaringan. Kemampuan pelumas semi padat pada putaran 700-3000 rpm kurang baik dikarenakan pada studi kasus ini, gearbox yang diterapkan adalah gearbox tertutup, sehingga suhu pada lingkungan kerja akan bertambah, sedangkan kelemahan pada pelumas semi padat yang didapat dari tabel 1 adalah tidak mampu menghilangkan panas atau kemampuan menghilangkan panas yang buruk, sehingga jika suhu gearbox tinggi, akan menyebabkan gearbox mengalami pemuaian dan pemuaian yang tidak disertai pendinginan (kontrol suhu) akan menyebabkan kerusakan pada gearbox. Pelumas semi pada tidak dapat dilakukan proses sirkulasi, penyaringan dan pendinginan dikarenakan memiliki viskositas yang sangat tinggi.

- Pelumas Cair

Pada pelumas cair, kemampuan menahan beban cukup baik dan kemampuan pada putaran 700-3000 rpm yang sangat baik. Hal ini dikarenakan pelumas cair dapat melapisi bagian bagian yang tidak dapat dijangkau oleh pelumas tipe lain karena viskositasnya rendah. Pelumas cair memiliki viskositas rendah, sehingga dapat dilakukan proses sirkulasi dan penyaringan, dengan adanya proses sirkulasi, maka pelumas cair dapat melakukan proses pendinginan pada mesin.

- Pelumas Gas

Pada pelumas gas, kemampuan menahan beban dan kemampuan pada putaran 700-3000 rpm tidak layak, namun dapat dilakukan proses sirkulasi, penyaringan, dan pendinginan. Kemampuan menahan beban dan kemampuan pada putaran 700-3000 rpm kurang layak pada pelumas gas, selain itu, adanya proses sirkulasi, penyaringan dan pendinginan tidak akan berpengaruh terhadap pelumasan pada mesin Honda Revo 100 cc. Hal tersebut dikarenakan kondisi kerja yang tidak sesuai dengan aplikasi pelumas gas yang telah diterapkan selama ini. Pelumas gas biasanya diaplikasikan pada kondisi khusus, seperti pada pelumasan bearing gas yang beroperasi pada kecepatan tinggi (+-65000 rpm) dan beban rendah. Berdasarkan kerangka berfikir, lingkungan kerja pelumas gas harus benar benar rapat, komponen komponen pendukung harus sangat presisi, beban harus rendah dan kecepatannya harus tinggi. Sedangkan pada studi kasus ini, gearbox menerima beban besar dari mesin dan kecepatan putarnya hanya 700-3000 rpm sehingga tidak memenuhi spesifikasi kerja dari pelumasan gas.

\section{Analisa Akhir}

Berdasarkan analisa yang telah dilakukan sebelumnya, didapatkan hasil akhir berupa tipe pelumas yang paling sesuai dengan kondisi mesin kerja sepeda motor Honda Revo 100 cc, yaitu pelumas cair. Hal ini dikarenakan pelumas cair memiliki keempat kemampuan yang dibutuhkan dalam kondisi kerja mesin Honda Revo 100 cc, antara lain kemampuan menerima beban yang cukup baik, kemampuan pada putaran 700-3000 rpm, kemampuan untuk disuplai, kemampuan untuk dilakukan penyaringan, serta kemampuan untuk mendinginkan komponen yang sangat baik.

\section{KESIMPULAN}

1. Kemampuan pelumas padat dalam menerima beban sangat baik dan kemampuan pada putaran 700-3000 rpm yang cukup baik, tapi sifat tersebut hanya sementara. Selain itu, pelumas padat tidak dapat dilakukan proses sirkulasi, penyaringan dan pendinginan.

2. Kemampuan pelumas semi padat dalam menerima beban sangat baik dan kemampuan pada putaran 700-3000 rpm yang kurang baik. Pelumas semi padat tidak dapat dilakukan proses sirkulasi, penyaringan. Selain itu pelumas semi padat 
memilki kemampuan pendinginan yang buruk.

3. Kemampuan pelumas cair dalam menerima beban dan kemampuan pada putaran 700 $3000 \mathrm{rpm}$ yang cukup baik,. Selain itu, pelumas padat dapat dilakukan proses sirkulasi, penyaringan dan pendinginan.

4. Pada pelumas gas, kemampuan menahan beban dan kemampuan pada putaran $700-$ $3000 \mathrm{rpm}$ tidak layak, namun dapat dilakukan proses sirkulasi, penyaringan, dan pendinginan, walaupun tidak berpengaruh terhadap kinerja pelumas gas terhadap studi kasus.

5. Berdasarkan analisa yang telah dilakukan sebelumnya, didapatkan hasil akhir berupa tipe pelumas yang paling sesuai dengan kondisi kerja sepeda motor Honda Revo $100 \mathrm{cc}$ adalah pelumas cair.

\section{DAFTAR PUSTAKA}

[1] Peterson M B and Winer W O, 1980, Wear control handbook, ASME.

[2] cuiet.info/notes/chemistry/Lubricants.pdf

[3] http://www.substech.com/dokuwiki/doku.p hp?id=solid_lubricants

[4] Powell, J.W., 1970, Design of Aerostatic Bearings, The Machinery Publishing Co. Ltd.

[5] Markdebenedetto, Phd, 1997, Lubricant Refence Manual, Technical Chesterton Products, USA

[6] Buku katalog suku cadang Honda Revo $100 \mathrm{cc}$, www.ahass.org-revo-100.pdf 